\title{
Perbandingan Kinerja Keuangan Perusahaan Asuransi Syariah Berdasarkan Early Warning System dan Risk-Based Capital pada PT Asuransi Jiwa Syariah Jasa Mitra Abadi Tbk Sebelum dan Sesudah Go Public
}

Comparison of financial performance of sharia insurance companies based on early warning system and risk-based capital on PT Asuransi Jiwa Syariah Jasa Mitra Abadi Tbke before and after go public

\section{Hizrina Awaliyah}

Program Studi D4 Keuangan Syariah, Politeknik Negeri Bandung

E-mail: hizrina.awaliyah@gmail.com

\section{Benny Barnas}

Jurusan Akuntansi, Politeknik Negeri Bandung

E-mail: benny.barnas@gmail.com

\begin{abstract}
The sharia insurance industry in 2019 experienced a slowdown, as seen from the indicators of assets, contributions and gross claims. In the sharia insurance industry, the only company that has gone public is PT Asuransi Jiwa Syariah Jasa Mitra Abadi Tbk. This study aims to determine how the company's financial performance is, and to find out whether there are differences in the company's financial performance before and after going public for the 2015-2019 period. The research method used is financial ratio analysis using the Early Warning System (EWS) and Risk. Based Capital (RBC) methods. The data analysis method used is a comparative descriptive analysis with a quantitative approach. The results showed that the company's financial performance after going public did not improve significantly.
\end{abstract}

Keywords: Financial Performance, EWS, RBC, Go Public

\section{Pendahuluan}

Go public adalah suatu aktivitas yang dilakukan perusahaan untuk memperoleh modal dari masyarakat umum dengan cara menjual saham perdananya. Sebagai konsekuensinya, perusahaan yang telah go public akan dituntut untuk lebih terbuka, dan dituntut untuk selalu meningkatkan tingkat pertumbuhan usahanya. Sesuai dengan peraturan yang diatur oleh Badan Pengawas Pasar Modal (Bapepam), perusahaan yang telah go public diwajibkan untuk mengungkapan informasi penting melalui laporan tahunan yang didalamnya sudah mencakup tentang laporan keuangan perusahaan.

Laporan keuangan merupakan sumber informasi bagi para stakeholders untuk menilai bagaimana kinerja keuangan perusahaan yang dapat membantu dalam proses pengambilan keputusan, untuk melakukan evaluasi atas kegiatan operasionalnya, serta dapat menentukan apakah operasional perusahaan sudah efektif atau belum (Nurdin et. al., 2020). Dalam mengukur dan menilai kinerja keuangan, umumnya perusahaan menggunakan suatu ukuran perbandingan yang biasa disebut dengan rasio keuangan. Terdapat berbagai macam jenis rasio keuangan, namun rasio keuangan yang digunakan antar perusahaan sering berbeda, karena disesuaikan dengan jenis usaha 
yang dijalankannya. Untuk perusahaan asuransi, salah satu metode analisis rasio keuangan yang digunakan adalah Early Warning System (EWS).

Early Warning System (EWS) merupakan tolak ukur perhitungan yang dibuat oleh The National Association of Insurance Commissioners (NAIC) atau lembaga pengawas badan usaha asuransi Amerika Serikat dalam mengukur kinerja keuangan dan menilai tingkat kesehatan perusahaan asuransi yang dilihat dari aspek-aspek rasio keuangan, yaitu rasio likuiditas, rasio solvabilitas, rasio profitabilitas, rasio stabilitas premi, dan rasio cadangan teknis. (Wulandari, 2011). Di Indonesia, metode Early Warning System (EWS) bagi perusahaan asuransi jiwa telah diatur dalam Pernyataan Standar Akuntansi Keuangan (PSAK) Nomor 36 tentang Akuntansi Asuransi Jiwa. Metode lain yang dapat digunakan untuk menilai kinerja keuangan perusahaan asuransi adalah Risk Based Capital (RBC). Berdasarkan Peraturan Menteri Keuangan Republik Indonesia Nomor 53/PMK.010/2012, Risk Based Capital (RBC) merupakan metode batas tingkat solvabilitas yang digunakan untuk mengukur kemampuan perusahaan asuransi dalam memenuhi semua kewajibannya dengan mempertimbangkan ukuran dan profil risiko yang dikelolanya. (Menteri Keuangan RI, 2012).

Berdasarkan laporan Otoritas Jasa Keuangan pada bulan November tahun 2019 indusri asuransi syariah mengalami pertumbuhan yang lambat dibandingkan tahun-tahun sebelumnya. Hal tersebut dapat dilihat pada tabel indikator industri asuransi syariah sebagai berikut:

Tabel. 1 Indikator Industri Asuransi Syariah

\begin{tabular}{|l|c|c|c|c|c|}
\hline \multicolumn{1}{|c|}{ Tahun } & 2015 & 2016 & 2017 & 2018 & 2019 \\
\hline Aset (Rp Miliar) & 25.400 & 32.538 & 38.668 & 42.435 & 44.751 \\
\hline \% Pertumbuhan & $16,82 \%$ & $28,10 \%$ & $18,84 \%$ & $9,74 \%$ & $5,46 \%$ \\
\hline Kontribusi Bruto (Rp Miliar) & 9.462 & 10.911 & 12.310 & 13.848 & 14.450 \\
\hline \% Pertumbuhan & $13,02 \%$ & $15,32 \%$ & $12,82 \%$ & $12,49 \%$ & $4,35 \%$ \\
\hline Klaim Bruto (Rp Miliar) & 3.003 & 4.018 & 4.325 & 6.940 & 9.471 \\
\hline \% Pertumbuhan & $11,11 \%$ & $33,80 \%$ & $7,64 \%$ & $60,45 \%$ & $36,48 \%$ \\
\hline
\end{tabular}

Sumber: Statistik IKNB Syariah tabun 2015-2019 (OJK) (OJK, 2019)

Terlihat pada Tabel 1 bahwa pada tahun 2019, aset dan kontribusi bruto mengalami pertumbuhan yang lambat dibandingkan tahun sebelumnya. Aset yang dimiliki industri asuransi syariah pada tahun 2019 bertumbuh secara lambat dengan persentase pertumbuhan sebesar 5,46\% atau Rp 44.751 miliar, dari tahun sebelumnya sebesar 9,47\%. Kemudian pada tahun 2019, kontribusi bruto industri asuransi syariah sebesar Rp 14.450 miliar bertumbuh secara lambat dari tahun sebelumnya 12,49\% menjadi 4,35\%. Angka pertumbuhan aset dan kontribusi bruto pada tahun 2019 tersebut merupakan angka pertumbuhan yang paling rendah selama lima tahun terakhir. Hal yang sama pun terjadi pada jumlah klaim bruto industri asuransi syariah yang mengalami penurunan pertumbuhan pada tahun 2019 sebesar Rp 9.471 miliar atau 36,48\% dari tahun sebelumnya $60,45 \%$.

Dalam hal ini perusahaan yang dimaksud adalah satu-satunya perusahaan di industri asuransi syariah yang telah go public dan mencatatkan sahamnya di Bursa Efek Indonesia (BEI), yakni PT Asuransi Jiwa Syariah Jasa Mitra Abadi Tbk. Penelitian ini dilakukan untuk mengetahui bagaimana kinerja keuangan perusahaan sebelum dan sesudah go public, serta untuk mengetahui apakah terdapat perbedaan kinerja keuangan perusahaan sebelum dan sesudah go public. Hasil penelitian ini diharapkan dapat bermanfaat bagi pembaca secara umum, dan menjadi sumber informasi mengenai kinerja keuangan perusahaan asuransi syariah yang telah go public, sehingga dapat dijadikan bahan pertimbangan dan pembanding bagi perusahaan asuransi syariah lain yang akan melakukan go public. Selain itu, perlu untuk terus memacu perkembangan industri keuangan syariah yang menurut Setyowati et. al., (2019) perkembangannya masih kalah dari pasar modal dan perbankan syariah. 


\section{Kajian Pustaka}

\subsection{Asuransi Jiwa Syariah}

Berdasarkan Undang-Undang Republik Indonesia Nomor 40 Tahun 2014 dan Peraturan Otoritas Jasa Keuangan Nomor 69/POJK.05/2016, Perusahaan Asuransi Jiwa Syariah adalah salah satu perusahaan yang menyelenggarakan usaha asuransi jiwa syariah, berupa pengelolaan risiko berdasarkan prinsip syariah guna saling menolong dan melindungi dengan memberikan pembayaran yang didasarkan pada meninggal atau hidupnya peserta, atau pembayaran lain kepada peserta atau pihak lain yang berhak pada waktu tertentu yang diatur dalam perjanjian, yang besarnya telah ditetapkan dan/atau didasarkan pada hasil pengelolaan dana perusahaan asuransi jiwa syariah dan unit syariah pada Perusahaan Asuransi Jiwa hanya dapat menyelenggarakan usaha asuransi jiwa termasuk lini usaha anuitas, lini usaha asuransi kesehatan, dan lini asuransi kecelakaan diri berdasarkan prinsip syariah. (OJK, 2016), (Republik Indonesia, 2014).

\subsection{Laporan Keuangan}

Menurut Fahmi (2017), laporan keuangan merupakan sumber informasi yang menggambarkan kondisi dan kinerja keuangan perusahaan. Sedangkan menurut Munawir (2012), laporan keuangan merupakan suatu alat yang sangat penting untuk mendapatkan informasi mengenai posisi keuangan dan hasil pencapaian perusahaan. Laporan keuangan dapat membantu para pemangku kepentingan untuk dapat mengetahui sudah sejauh mana perusahaan telah mencapai tujuannya. (Fahmi, 2017).

\subsection{Kinerja Keuangan}

Kondisi suatu perusahaan dicerminkan oleh kinerja yang dicapai oleh perusahaan. (Setyowati, 2018; Setiawan et. al., 2020). Kinerja keuangan merupakan suatu alat yang diperlukan oleh analis keuangan untuk menilai prestasi, dan kondisi keuangan perusahaan. (Husnan, 2007). Sedangkan menurut Rudianto (2013), kinerja keuangan merupakan hasil atau prestasi yang telah dicapai oleh manajemen perusahaan dalam menjalankan fungsinya mengelola aset perusahaan secara efektif pada periode tertentu. (Rudianto, 2013). Pendapat lain disampaikan oleh Fahmi (2017), kinerja keuangan adalah suatu analisis yang dilakukan dengan menggunakan aturan-aturan pelaksanaan keuangan secara baik dan benar, yang bertujuan untuk melihat sejauh mana suatu perusahaan telah melaksanakan kegiatan operasionalnya. (Fahmi, 2017).

Pengukuran kinerja perusahaan merupakan bagian dari proses analisis kinerja keuangan (Taruna \& Setiawan, 2019). Menurut Harmono (2014), analisis kinerja keuangan merupakan suatu proses dengan tujuan untuk mendalami kinerja keuangan perusahaan secara kritis yang ditinjau dari data keuangan, perhitungan, pengukuran, interpretasi, dan pemberian solusi terhadap masalah keuangan yang dialami perusahaan pada periode tertentu. (Farihah \& Setiawan, 2020).

\subsection{Rasio Keuangan}

Umumnya, investor lebih banyak tertarik kepada kondisi keuangan jangka pendek dan bagaimana kemampuan perusahaan untuk membayar dividen. Kebutuhan informasi tersebut dapat diketahui dengan cara menghitung rasio-rasio keuangan yang sesuai dengan kebutuhan. Proses untuk menghitung rasio-rasio keuangan tersebut biasa disebut dengan analisis rasio keuangan. Analisis rasio keuangan merupakan suatu alat yang digunakan untuk mengukur kinerja keuangan dan menilai tingkat kesehatan keuangan perusahaan, yang menyangkut review data, perhitungan, perbandingan hasil, penafsiran, serta pemecahan suatu masalah. (Fahmi, 2017).

\subsection{Early Warning System}

Di Indonesia, rasio-rasio keuangan dari metode Early Warning System (EWS) yang dipakai untuk perusahaan asuransi jiwa telah diatur dalam Pernyataan Standar Akuntansi Keuangan (PSAK) Nomor 36 tentang Akuntansi Asuransi Jiwa. Rasio-rasio keuangan yang terdapat dalam 
PSAK Nomor 36 diantaranya:

\section{a. Solvency Ratio (Rasio Batas Tingkat Solvabilitas)}

Solvency Ratio adalah rasio yang digunakan untuk menilai kemampuan perusahaan asuransi dalam memenuhi kewajibannya kepada pemegang polis yang dicerminkan dengan perbandingan antara nilai kekayaan yang diperkenankan dengan kewajiban perusahaan. Solvency Ratio memiliki batas normal minimal sebesar 33,3\%.(Nurfadila et al., 2015). Rasio batas tingkat solvabilitas ini dapat diukur dengan menggunakan rumus sebagai berikut:

$$
\text { Solvency Ratio }=\frac{\text { Aktiva yang Diperkenankan }}{\text { Total Kewajiban }} \times 100 \%
$$

Sumber: PS AK No. 36 (IAI, 2010)

\section{b. Profitability Ratio (Rasio Profitabilitas)}

Rasio Profitabilitas merupakan rasio yang digunakan untuk menunjukkan keberhasilan perusahaan dalam menghasilkan keuntungan. Kemampuan perusahaan dalam menghasilkan laba merupakan fokus utama dalam penilaian prestasi perusahaan, selain itu juga merupakan elemen penting dalam menentukan nilai perusahaan. (Hijriyani \& Setiawan, 2017). Aspek Rasio Profitabilitas pada penelitian ini ditunjukkan oleh perhitungan rasio beban klaim dan rasio pengembalian investasi.

\section{- Loss Ratio (Rasio Beban Klaim)}

Rasio Beban Klaim adalah rasio yang digunakan untuk menunjukkan pengalaman klaim yang terjadi pada perusahaan dan mengukur kualitas dari asuransi yang ditutup serta menunjukkan kemampuan perusahaan dalam memenuhi klaim yang diajukan pemegang polis. Rasio ini memiliki batas normal maksimal 100\%, sehingga rasio beban klaim dikatakan sehat apabila nilai rasio kurang dari 100\%. (Nurfadila et al., 2015). Perhitungan rasio beban klaim dapat dihitung dengan rumus:

$$
\text { Rasio Beban Klaim }=\frac{\text { Beban Klaim }}{\text { Pendapatan Premi }} \times 100 \%
$$

Sumber: PSAK No. 36 (IAI, 2010)

\section{- Investment Yield Ratio (Rasio Pengembalian Investasi)}

Rasio Pengembalian Investasi adalah rasio yang digunakan untuk mengukur kualitas setiap jenis investasi dan mengukur hasil yang dicapai dari investasi yang dilakukan. Rasio ini memiliki batas normal minimal 15\%, sehingga rasio pengembalian investasi dapat dikatakan sehat apabila nilai rasio lebih dari 15\%. (Nurfadila et al., 2015). Perhitungan rasio pengembalian investasi dapat dihitung dengan rumus:

$$
\text { Rasio Pengembalian Investasi }=\frac{\text { Pendapatan Bersih Investasi }}{\text { Rata }- \text { Rata Investasi }} \times 100 \%
$$

Sumber: PS AK No. 36 (IAI, 2010)

\section{c. Liquidity Ratio (Rasio Likuiditas Aset)}

Rasio likuiditas merupakan rasio yang digunakan untuk mengukur kemampuan perusahaan dalam memenuhi kewajiban jangka pendek dan memberikan gambaran apakah kondisi keuangan perusahaan sedang dalam kondisi yang likuid atau tidak. Rasio ini memiliki batas normal maksimal $120 \%$, sehingga rasio likuiditas dapat dikatakan sehat apabila nilai rasio kurang dari 120\%. (Nurfadila et al., 2015). Perhitungan rasio likuiditas aset dapat dihitung dengan rumus:

$$
\text { Rasio Likuiditas }=\frac{\text { Total Kewajiban }}{\text { Aktiva yang diperkenankan }} \times 100 \%
$$

Sumber: PSAK No. 36 (IAI, 2010) 


\section{d. Premium Stability Ratio (Rasio Pertumbuhan Premi)}

Rasio pertumbuhan premi adalah rasio yang digunakan untuk menunjukkan seberapa besar kenaikan premi pada tahun berjalan dibandingkan tahun sebelumnya. Batas normal untuk rasio pertumbuhan premi minimal 23\%, sehingga rasio pertumbuhan premi dapat dikatakan sehat apabila nilai rasio lebih dari 23\%. (Nurfadila et al., 2015). Perhitungan rasio pertumbuhan premi dapat dihitung dengan rumus:

$$
\text { Rasio Pertumbuhan Premi }=\frac{\text { Naik/Turun Premi Neto }}{\text { Premi Neto tahun lalu }} \times 100 \%
$$

Sumber: PSAK No. 36 (IAI, 2010)

\section{e. Technical Ratio (Rasio Cadangan Teknis)}

Rasio cadangan teknis adalah rasio yang menggambarkan tingkat kecukupan cadangan yang diperlukan dalam menghadapi kewajiban yang timbul dari penutupan risiko. Rasio cadangan tidak memiliki batas normal, namun tinggi rendahnya rasio perlu diperhatikan apakah memberikan indikasi yang baik atau tidak. (Nurfadila et al., 2015). Perhitungan rasio cadangan teknis dapat dihitung dengan rumus:

Sumber: PSAK No. 36 (IAI, 2010)

$$
\text { Rasio Cadangan Teknis }=\frac{\text { Kewajiban Teknis }}{\text { Premi Neto }} \times 100 \%
$$

\subsection{Risk Based Capital}

Berdasarkan Peraturan Menteri Keuangan Republik Indonesia Nomor 53/PMK.10/2012 tentang Kesehatan Keuangan Perusahaan Asuransi dan Perusahaan Reasuransi, tingkat kesehatan perusahaan asuransi baik asuransi konvensional maupun syariah dinilai dengan menggunakan metode Risk Based Capital. Risk Based Capital (RBC) merupakan metode batas tingkat solvabilitas yang digunakan untuk mengukur kemampuan perusahaan asuransi dalam memenuhi semua kewajibannya dengan mempertimbangkan ukuran dan profil risiko yang dikelolanya. (Menteri Keuangan RI, 2012).

Perusahaan asuransi dan perusahaan reasuransi syariah di Indonesia wajib memiliki tingkat solvabilitas (Risk Based Capital) minimal 120\% pada dana tabarru' dan dana perusahaan. Perhitungan rasio Risk Based Capital dapat dihitung dengan rumus:

$$
\text { Risk Based Capital }=\frac{\text { Tingkat Solvabilitas }}{\text { Batas Tk. Solvabilitas Min. }} \times 100 \%
$$

Sumber: KMK Nomor 424/KMK.06/2003 (Menteri Keuangan RI, 2003)

\subsection{Go Public}

Go public atau Initial Public Offering (IPO) dilakukan dengan tujuan untuk pengembangan atau ekspansi usaha, memperbaiki dan memperkuat struktur modal, membayar utang, meningkatkan likuiditas dan memperkenalkan perusahaan kepada publik. Pada persiapan awal proses menjadi perusahaan publik, perusahaan akan membentuk tim IPO internal untuk membantu perusahaan dalam proses IPO, khususnya dalam mempersiapkan dokumen prospektus.

Prospektus merupakan dokumen yang berisi sejumlah informasi akuntansi dan non akuntansi dari perusahaan, seperti laporan keuangan yang telah di audit, profil perusahaan, informasi tentang rencana IPO, underwriter dan profesi penunjang, serta anggaran dasar perusahaan dan laporan pemeriksaan dari konsultan hukum. (Widjaja \& Risnamanitis, 2009). 


\section{Metode Penelitian}

\subsection{Metode Penelitian}

Metode penelitian yang digunakan dalam penelitian ini adalah penelitian deskriptif komparatif dengan pendekatan kuantitatif. Pendekatan kuantitatif menurut Kasiram (2008) adalah proses yang bertujuan untuk menemukan informasi dengan menggunakan data berupa angka sebagai alat untuk menganalisis apa yang ingin diketahui. (Kasiram, 2008).

\subsection{Teknik Pengambilan Sampel}

Teknik pengambilan sampel yang digunakan adalah metode purposive sampling. Menurut Sugiyono (2012), purposive sampling adalah teknik yang digunakan untuk menentukan sampel dengan membuat pertimbangan tertentu. (Sugiyono, 2012). Beberapa pertimbangan yang diambil dalam pengambilan sampel adalah sebagai berikut:

1) Merupakan perusahaan asuransi jiwa syariah yang telah mencatatkan sahamnya di Bursa Efek Indonesia (BEI) atau dikenal dengan go public.

2) Telah mepublikasikan laporan keuangan tahunan pada tahun penelitian, yaitu tahun 20152019.

Berdasarkan beberapa pertimbangan tersebut, maka objek pada penelitian ini adalah PT Asuransi Jiwa Syariah Jasa Mitra Abadi Tbk yang telah melakukan IPO pada tahun 2017.

\subsection{Data Penelitian}

Data yang digunakan dalam penelitian ini adalah data sekunder, yaitu data yang dikumpulkan dari sumber yang telah ada, yang dapat di akses melalui internet, penelusuran dokumen atau publikasi informasi.(Astungkarasari, 2017). Jenis data yang digunakan dalam penelitian ini adalah data kuantitatif, yaitu data yang berupa angka atau bilangan. (Fitrianti, 2015).

Penelitian ini juga menggunakan data time series. Data time series merupakan salah satu jenis data yang dikumpulkan menurut urutan waktu dalam suatu rentang waktu tertentu.(Dictio.id, 2018). Jenis data yang digunakan adalah time series, karena penelitian dilakukan secara beruntun dalam kurun waktu 5 (lima) tahun, yaitu mulai dari tahun 2015 sampai dengan tahun 2019.

Sumber data yang digunakan merupakan data kuantitatif yang diperoleh dari situs resmi PT Asuransi Jiwa Syariah Jasa Mitra Abadi Tbk (http://jmasyariah.com). Data yang digunakan dalam penelitian ini berupa laporan keuangan tahunan PT Asuransi Jiwa Syariah Jasa Mitra Abadi Tbk periode 2015-2019, yaitu laporan neraca dan laporan laba rugi.

\subsection{Teknik Analisis Data}

Adapun langkah-langkah yang akan digunakan dalam penelitian ini adalah sebagai berikut:

1. Menghitung dan menganalisis laporan keuangan perusahaan asuransi syariah dengan menggunakan alat rasio keuangan dengan metode early warning system, yaitu rasio profitabilitas yang ditunjukkan dengan rasio beban klaim dan rasio pengembalian investasi, rasio likuiditas, rasio pertumbuhan premi, rasio cadangan teknis, serta rasio solvabilitas yang ditunjukkan dengan rasio risk based capital.

2. Melakukan analisis data berupa pengujian normalitas data.

3. Melakukan analisis dengan pengolahan data untuk membandingkan kinerja keuangan perusahaan asuransi syariah sebelum dan sesudah go public dengan menggunakan uji hipotesis. Hipotesis yang ditentukan dalam pengujian ini adalah:

Ho : tidak terdapat perbedaan antara kinerja keuangan perusahaan dengan menggunakan metode Early Warning System dan metode Risk Based Capital sebelum dan sesudah go public.

$\mathrm{Ha}$ : terdapat perbedaan antara kinerja keuangan perusahaan dengan menggunakan metode Early Warning System dan metode Risk Based Capital sebelum dan sesudah go public. 


\section{Hasil dan Pembahasan}

\subsection{Analisis Kinerja Keuangan Sebelum dan Sesudah Go Public}

Perusahaan yang menjadi obyek pada penelitian ini adalah PT Asuransi Jiwa Syariah Jasa Mitra Abadi Tbk yang telah melakukan kegiatan go public pada akhir tahun 2017. Sehingga analisis kinerja keuangan perusahaan sebelum go public dilakukan selama 2 tahun, yaitu dari tahun 2015 hingga tahun 2016. Sedangkan analisis kinerja keuangan perusahaan sesudah go public dilakukan selama 3 tahun, yaitu dari tahun 2017 hingga tahun 2019. Analisis kinerja keuangan perusahaan dilakukan dengan menggunakan dua macam metode, yaitu metode Early Warning System dan Risk Based Capital.

1. Metode Early Warning System

a. Profitability Ratio (Rasio Profitabilitas)

- Loss Ratio (Rasio Beban Klaim)

Berikut hasil perhitungan dan pertumbuhan dari Rasio Beban Klaim:

Tabel. 2 Rasio Beban Klaim Tahun 2015-2019

\begin{tabular}{|c|c|c|}
\hline Tahun & Rasio Beban Klaim & Pertumbuhan \\
\hline 2015 & $3.84 \%$ & - \\
\hline 2016 & $47.18 \%$ & $43.34 \%$ \\
\hline 2017 & $40.85 \%$ & $-6.33 \%$ \\
\hline 2018 & $78.73 \%$ & $37.87 \%$ \\
\hline 2019 & $137.95 \%$ & $59.22 \%$ \\
\hline
\end{tabular}

Sumber: data diolah (2020) (JMA Syariah, 2020)

Berdasarkan Tabel 2 diatas, dapat dilihat bahwa baik sebelum maupun sesudah go public nilai rasio beban klaim berada dalam batas normal, sehingga rasio dikategorikan sehat. Hal tersebut menandakan bahwa perusahaan mampu membayar klaim dengan menggunakan pendapatan premi yang diperoleh.

\section{- Investment Yield Ratio (Rasio Pengembalian Investasi)}

Berikut hasil perhitungan dan pertumbuhan Rasio Pengembalian Investasi dapat dilihat pada tabel dibawah ini:

Tabel. 3 Rasio Pengembalian Investasi Tahun 2015 - 2019

\begin{tabular}{|c|c|c|}
\hline Tahun & Rasio Pengembalian Investasi & Pertumbuhan \\
\hline 2015 & $9.44 \%$ & - \\
\hline 2016 & $6.94 \%$ & $-2.50 \%$ \\
\hline 2017 & $5.46 \%$ & $-1.48 \%$ \\
\hline 2018 & $9.61 \%$ & $4.15 \%$ \\
\hline 2019 & $8.07 \%$ & $-1.54 \%$ \\
\hline
\end{tabular}

Sumber: data diolah, (2020) (JMA Syariah, 2020)

Berdasarkan Tabel 3 diatas, dapat dilihat bahwa baik sebelum maupun sesudah go public nilai rasio pengembalian investasi berada di luar batas normal, sehingga rasio dikategorikan kurang sehat. Hal ini menandakan bahwa kemampuan perusahaan untuk memperoleh hasil dari investasi yang dilakukan belum maksimal. Sehingga perusahaan perlu untuk mencari alternatif kegiatan Investasi lain yang dinilai lebih menguntungkan.

\section{b. Liquidity Ratio (Rasio Likuiditas Aset)}

Berikut hasil perhitungan dan pertumbuhan Rasio Likuiditas Aset dapat dilihat pada tabel 
dibawah ini:

Tabel. 4 Rasio Likuiditas Tahun 2015 - 2019

\begin{tabular}{|c|c|c|}
\hline Tahun & Rasio Likuiditas Aset & Pertumbuhan \\
\hline 2015 & $5.46 \%$ & - \\
\hline 2016 & $11.82 \%$ & $6.36 \%$ \\
\hline 2017 & $31.85 \%$ & $20.03 \%$ \\
\hline 2018 & $38.74 \%$ & $6.90 \%$ \\
\hline 2019 & $58.21 \%$ & $19.47 \%$ \\
\hline
\end{tabular}

Sumber: data diolah (2020) (JMA Syariah, 2020)

Berdasarkan Tabel 4 diatas, dapat dilihat bahwa baik sebelum maupun sesudah go public nilai rasio likuiditas aset berada dalam batas normal, sehingga rasio dikategorikan sehat. Hal tersebut menandakan bahwa perusahaan berada dalam keadaan yang likuid atau sehat dan menunjukkan bahwa perusahaan mampu memenuhi kewajibannya dengan harta yang dimiliki.

\section{c. Premium Stability Ratio (Rasio Pertumbuhan Premi)}

Berikut hasil perhitungan Rasio Pertumbuhan Premi dapat dilihat pada tabel dibawah ini:

Tabel. 5 Rasio Pertumbuhan Premi Tahun 2015 - 2019

\begin{tabular}{|c|c|c|}
\hline Tahun & Rasio Pertumbuhan Premi & Pertumbuhan \\
\hline 2015 & $100.00 \%$ & - \\
\hline 2016 & $167.17 \%$ & $67.17 \%$ \\
\hline 2017 & $207.86 \%$ & $40.69 \%$ \\
\hline 2018 & $-7.55 \%$ & $-215.41 \%$ \\
\hline 2019 & $99.26 \%$ & $106.81 \%$ \\
\hline
\end{tabular}

Sumber: data diolah (2020) (JMA Syariah, 2020)

Berdasarkan Tabel 5 diatas, dapat dilihat bahwa nilai rasio pertumbuhan premi baik sebelum maupun sesudah go public rata-rata bernilai lebih dari $23 \%$ dan berada dalam batas normal. Hal tersebut menandakan bahwa rasio pertumbuhan premi dikategorikan sehat. Kecuali pada tahun 2018, nilai rasio pertumbuhan premi bernilai negatif, yang berarti bahwa rasio dikategorikan kurang sehat.

\section{d. Technical Ratio (Rasio Cadangan Teknis)}

Berikut hasil perhitungan dan pertumbuhan Rasio Cadangan Teknis dapat dilihat pada tabel dibawah ini:

Tabel. 6 Rasio Cadangan Teknis Tahun 2015-2019

\begin{tabular}{|c|c|c|}
\hline Tahun & Rasio Cadangan Teknis & Pertumbuhan \\
\hline 2015 & $82.43 \%$ & - \\
\hline 2016 & $113.56 \%$ & $31.13 \%$ \\
\hline 2017 & $297.59 \%$ & $184.03 \%$ \\
\hline 2018 & $408.65 \%$ & $111.06 \%$ \\
\hline 2019 & $261.38 \%$ & $-147.27 \%$ \\
\hline
\end{tabular}

Sumber: data diolah, (2020) (JMA Syariah, 2020)

Berdasarkan Tabel 6 diatas, dapat dilihat bahwa nilai rasio cadangan teknis baik sebelum maupun sesudah go public memiliki nilai yang cukup tinggi. Hal tersebut menandakan bahwa perusahaan memiliki cadangan yang besar dalam memenuhi kewajiban yang mungkin timbul di masa depan. Namun nilai rasio termasuk dalam kategori yang tinggi, sehingga dapat dikatakan 
bahwa portofolio usaha perusahaan masih kurang merata.

\section{Metode Risk Based Capital}

Berikut hasil perhitungan Risk Based Capital untuk dana tabarru':

Tabel. 7 Risk Based Capital Dana Tabarru' Tahun 2015 - 2019

\begin{tabular}{|c|c|c|}
\hline Tahun & Risk Based Capital - Dana Tabarru' & Pertumbuhan \\
\hline 2015 & $83.07 \%$ & - \\
\hline 2016 & $49.53 \%$ & $-33.55 \%$ \\
\hline 2017 & $65.44 \%$ & $15.91 \%$ \\
\hline 2018 & $107.60 \%$ & $42.16 \%$ \\
\hline 2019 & $-299.87 \%$ & $-407.47 \%$ \\
\hline
\end{tabular}

Sumber: data diolah (2020) (JMA Syariah, 2020)

Berdasarkan Tabel 7 diatas, dapat dilihat bahwa baik sebelum maupun sesudah go public nilai rasio Risk Based Capital dana tabarru' berada di luar batas normal, sehingga rasio dikategorikan kurang sehat. Hal tersebut dikarenakan kemampuan perusahaan dalam memenuhi kewajibannya termasuk untuk membiayai setiap risiko pertanggungan perusahaan. Sehingga perusahaan diwajibkan untuk menyampaikan rencana penyehatan yang disetujui oleh pemegang saham dan dimonitor oleh Departemen Keuangan. Berikut hasil perhitungan Risk Based Capital untuk dana perusahaan dapat dilihat pada tabel dibawah ini:

Tabel. 8 Risk Based Capital Dana Perusahaan Tahun 2015 - 2019

\begin{tabular}{|c|c|c|}
\hline Tahun & Risk Based Capital - Dana Perusahaan & Pertumbuhan \\
\hline 2015 & $100.15 \%$ & - \\
\hline 2016 & $126.45 \%$ & $26.31 \%$ \\
\hline 2017 & $1993.10 \%$ & $1866.65 \%$ \\
\hline 2018 & $1421.28 \%$ & $-571.83 \%$ \\
\hline 2019 & $2024.43 \%$ & $603.15 \%$ \\
\hline
\end{tabular}

Sumber: data diolah (2020) (JMA Syariah, 2020)

Berdasarkan Tabel 8 diatas, dapat dilihat bahwa nilai rasio RBC dana perusahaan rata-rata baik sebelum maupun sesudah go public bernilai lebih dari 120\% dan berada dalam batas normal. Sehingga rasio dikategorikan sehat. Hal ini menunjukkan bahwa perusahaan sedang dalam kondisi yang sehat dan menandakan bahwa perusahaan mampu memenuhi kewajibannya.

\subsection{Hasil Analisis Data}

Berikut adalah hasil analisis data yang dilakukan menggunakan software SPSS 22.

\section{Pengujian Normalitas Data}

Pada penelitian ini uji normalitas menggunakan Shapiro Wilk dikarenakan jumlah data yang diteliti kurang dari 50 data, sehingga akan lebih akurat apabila menggunakan Shapiro-Wilk dibandingkan dengan Kolmogoro -Smirno. Data dikatakan berdistribusi normal apabila nilai signifikansi $>0,05$ dan dikatakan berdistribusi tidak normal apabila nilai signifikansi $<0,05$.

\section{Hasil Uji Normalitas Metode Early Warning System}

Berikut adalah hasil uji normalitas pada rasio keuangan dengan metode Early Warning System menggunakan software SPSS 22. 
Tabel. 9 Uji Normalitas Early Warning System

\begin{tabular}{|l|c|c|c|c|c|c|}
\hline \multirow{2}{*}{} & \multicolumn{2}{|c|}{ Kolmogorov-Smirnov $^{\mathrm{a}}$} & \multicolumn{4}{|c|}{ Shapiro-Wilk } \\
\cline { 2 - 7 } & Statistic & $\mathrm{df}$ & Sig. & Statistic & $\mathrm{df}$ & Sig. \\
\hline Risk Based Capital Dana Tabarru' - Sebelum & .180 & 3 & & .999 & 3 & .943 \\
\hline Risk Based Capital Dana Tabarru' - Sesudah & .351 & 3 & & .827 & 3 & .180 \\
\hline Risk Based Capital Dana Perusahaan - Sebelum & .381 & 3 & & .760 & 3 & .023 \\
\hline Risk Based Capital Dana Perusahaan - Sesudah & .369 & 3 & & .789 & 3 & .088 \\
\hline
\end{tabular}

Sumber: Hasil Output SPSS 22

Berdasarkan hasil output uji normalitas pada Tabel 9 diatas, dapat dilihat pada kolom Shapiro-Wilk bahwa rata-rata rasio pada metode Early Warning System sebelum dan sesudah go public memiliki nilai signifikansi lebih dari 0,05 . Hal tersebut menandakan bahwa data berdistribusi normal dan pengujian hipotesis dapat dilakukan dengan menggunakan uji Paired Sample T-Test atau uji hipotesis parametrik.

\section{a) Hasil Uji Normalitas Metode Risk Based Capital}

Berikut adalah hasil uji normalitas pada rasio keuangan dengan metode Early Warning System menggunakan software SPSS 22.

Tabel. 10 Uji Normalitas Risk Based Capital

\begin{tabular}{|l|c|c|c|c|c|c|}
\hline \multirow{2}{*}{} & \multicolumn{2}{|c|}{ Kolmogoro-Smirnov $^{\mathrm{a}}$} & \multicolumn{3}{|c|}{ Shapiro-Wilk } \\
\cline { 2 - 7 } & Statistic & $\mathrm{df}$ & Sig. & Statistic & df & Sig. \\
\hline Risk Based Capital Dana Tabarru' - Sebelum & .180 & 3 & & .999 & 3 & .943 \\
\hline Risk Based Capital Dana Tabarru' - Sesudah & .351 & 3 & & .827 & 3 & .180 \\
\hline Risk Based Capital Dana Perusahaan - Sebelum & .381 & 3 & & .760 & 3 & .023 \\
\hline Risk Based Capital Dana Perusahaan - Sesudah & .369 & 3 & & .789 & 3 & .088 \\
\hline
\end{tabular}

Sumber: Hasil Output SPSS 22

Berdasarkan hasil output uji normalitas pada Tabel 10 diatas, dapat dilihat pada kolom Shapiro-Wilk bahwa rata-rata rasio risk based capital memiliki nilai signifikansi lebih dari 0,05. Dikarenakan terdapat satu rasio yang memiliki nilai signifikansi kurang dari 0,05 dan data tidak berdistribusi normal, maka uji hipotesis yang sebaiknya digunakan adalah Wilcoxon Signed Rank Test atau uji hipotesis non-parametrik.

\section{Pengujian Hipotesis}

Pengujian hipotesis dilakukan untuk mengetahui apakah terdapat perbedaan kinerja keuangan perusahaan sebelum dan sesudah go public untuk periode tahun 2015-2019. Kriteria pengujian hipotesis pada penelitian ini adalah:

- Ho ditolak jika nilai probabilitas atau signifikansi kurang dari 0,05 berarti terdapat perbedaan antara kinerja keuangan perusahaan sebelum dan sesudah go public.

- Ho diterima jika nilai probabilitas atau signifikansi lebih dari 0,05 berarti tidak terdapat perbedaan antara kinerja keuangan perusahaan sebelum dan sesudah go public.

a) Hasil Pengujian Hipotesis Metode Early Warning System

Berikut adalah hasil uji hipotesis dari masing-masing rasio pada metode Early Warning System dengan menggunakan software SPSS 22. 
Tabel. 11 Uji Hipotesis Early Warning System

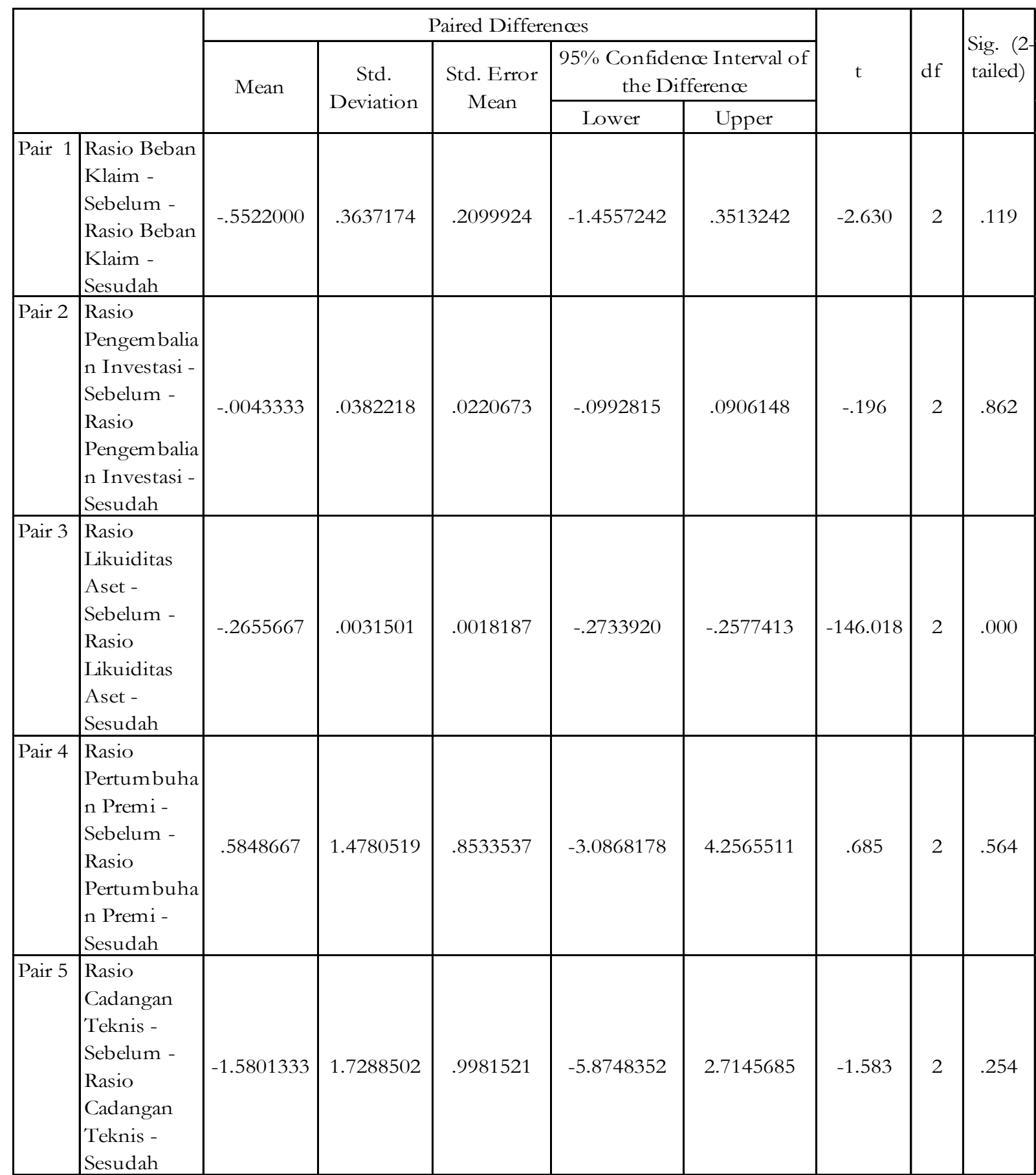

Sumber: Hasil Output SPSS 22

Berdasarkan Tabel 11, terlihat bahwa nilai signifikansi untuk rata-rata masing-masing rasio, yaitu rasio beban klaim sebelum dan sesudah go public, rasio pengembalian investasi sebelum dan sesudah go public, rasio pertumbuhan premi sebelum dan sesudah go public, dan rasio cadangan teknis sebelum dan sesudah go public lebih besar dari 0,05 adalah 0,$119 ; 0,862 ; 0,564$; dan 0,254. Namun untuk nilai signifikansi rasio likuiditas aset sebelum dan sesudah go public bernilai lebih kecil dari 0,05, yaitu 0,000. Meskipun demikian, secara mayoritas nilai signifikansi lebih besar dari 0,05, maka dapat disimpulkan bahwa $\mathrm{Ho}_{1}$ diterima dan $\mathrm{Ha}_{1}$ ditolak, yang berarti bahwa tidak terdapat perbedaan kinerja keuangan perusahaan dengan menggunakan metode Early Warning System. 
Dengan kata lain, setelah melakukan go public dan menjadi perusahaan public, kinerja keuangan PT Asuransi Jiwa Syariah Jasa Mitra Abadi, Tbk tidak mengalami peningkatan kinerja berdasarkan metode Early Warning System.

\section{b) Hasil Pengujian Hipotesis Metode Risk Based Capital}

Berikut adalah hasil uji hipotesis dari masing-masing rasio pada metode Risk Based Capital dengan menggunakan software SPSS 22.

Tabel. 12 Uji Hipotesis Risk Based Capital

\begin{tabular}{|l|c|c|}
\hline & $\begin{array}{c}\text { Risk Based Capital Dana Tabarru' - } \\
\text { Sesudah - Risk Based Capital Dana } \\
\text { Dana Tabarru' - Sebelum }\end{array}$ & $\begin{array}{c}\text { Risk Based Capital Dana Perusahaan - } \\
\text { Sesudah - Risk Based Capital Dana } \\
\text { Perusahaan - Sebelum }\end{array}$ \\
\hline Z & $-.535^{\mathrm{b}}$ & $-1.604^{\mathrm{c}}$ \\
\hline Asymp. Sig. (2-tailed) & .593 & .109 \\
\hline
\end{tabular}

Sumber: Hasil Output SPSS 22

Berdasarkan Tabel 12, terlihat bahwa nilai signifikansi untuk masing-masing rasio, yaitu rasio Risk Based Capital Dana Tabarru' sebelum dan sesudah go public, dan rasio Risk Based Capital Dana Perusahaan sebelum dan sesudah go public lebih besar dari 0,05, yaitu sebesar 0,593 dan 0,109. Maka dapat disimpulkan bahwa $\mathrm{Ho}_{2}$ diterima dan $\mathrm{Ha}_{2}$ ditolak, yang berarti bahwa tidak terdapat perbedaan kinerja keuangan perusahaan dengan menggunakan metode Risk Based Capital. Dengan kata lain, setelah melakukan go public dan menjadi perusahaan public, kinerja keuangan PT Asuransi Jiwa Syariah Jasa Mitra Abadi, Tbk tidak mengalami peningkatan kinerja berdasarkan metode Risk Based Capital.

\section{Penutup}

\subsection{Kesimpulan}

Berdasarkan pengolahan data dan hasil pengujian menggunakan analisis deskriptif komparatif mengenai kinerja keuangan PT Asuransi Jiwa Syariah Jasa Mitra Abadi, Tbk dapat disimpulkan bahwa tidak terdapat perbedaan kinerja keuangan perusahaan antara sebelum dan sesudah go public. Hal ini terlihat dari rasio-rasio keuangan yang menunjukkan hasil yang sama pada sebelum dan sesudah go public, yaitu rasio beban klaim, rasio likuiditas aset, rasio pertumbuhan premi, rasio Risk Based Capital Dana Perusahaan yang dikategorikan sehat, serta rasio pengembalian investasi, rasio cadangan teknis, dan rasio Risk Based Capital Dana Tabarru' yang dikategorikan kurang sehat. Sehingga dapat dikatakan bahwa setelah melakukan go public kinerja keuangan perusahaan tidak terjadi perbaikan yang cukup signifikan.

\subsection{Saran}

Berdasarkan hasil penelitian dan kesimpulan yang telah diuraikan, maka terdapat beberapa saran diantaranya sebagai berikut:

1. Bagi peneliti selanjutnya, diharapkan dapat menambah periode penelitian agar dapat lebih terlihat perkembangan dan pertumbuhan kinerja keuangan dari perusahaan. Selain menambah periode penelitian, peneliti selanjutnya diharapkan dapat meneliti dan menganalisis kinerja keuangan perusahaan per triwulan atau per bulan, sehingga analisis yang dilakukan dapat lebih detail dan rinci.

2. Bagi perusahaan, diharapkan dapat melakukan evaluasi kinerja keuangan dan berusaha untuk meningkatkan kinerjanya terutama dalam hal rasio pengembalian investasi, rasio cadangan teknis, dan rasio Risk Based Capital Dana Tabarru'. Serta diharapkan perusahaan dapat mempertahankan nilai rasio beban klaim, rasio likuiditas aset, rasio pertumbuhan premi, dan rasio Risk Based Capital Dana Perusahaan dalam kondisi yang sehat. Peningkatan kinerja 
keuangan dalam hal rasio pengembalian investasi dapat dilakukan dengan cara mencari alternatif kegiatan investasi lain yang dinilai lebih menguntungkan. Kemudian untuk mengontrol kinerja keuangan dalam hal rasio cadangan teknis dapat dilakukan dengan cara memperhatikan jumlah cadangan teknis yang dibentuk perusahaan, disesuaikan dengan kebutuhan agar mampu menghadapi kewajiban yang timbul dari penutupan risiko. Untuk rasio Risk Based Capital Dana Tabarru' dapat ditingkatkan dengan cara meningkatkan tingkat solvabilitas perusahaan agar dapat dikatakan solvabel dan memenuhi standar yang ditentukan oleh pemerintah.

3. Bagi industri asuransi syariah, khususnya perusahaan asuransi jiwa syariah sebaiknya dapat melakukan analisis kinerja keuangan terlebih dahulu sebelum melakukan go public dan merubah statusnya menjadi perusahaan public. Agar setelah go public perusahaan dapat memperoleh peningkatan kinerja keuangan seperti yang diharapkan, dan tidak membuat perusahaan memutuskan kebijakan yang kurang tepat.

4. Bagi investor, sebaiknya dapat mempelajari terlebih dahulu kinerja keuangan perusahaan sebelum benar-benar melakukan kegiatan investasi pada perusahaan go public. Agar harapan yang diinginkan oleh investor dapat tercapai, yaitu memperoleh keuntungan.

\section{Daftar Pustaka}

Astungkarasari, P. (2017). Pengarub Kinerja Kenangan Bank Panin Syariab Sebelum dan Sesudah Go Public Terhadap Return Saham Periode Tabun 2011-2016. Universitas Islam Negeri Maulana Malik Ibrahim, Malang.

Dictio.id. (2018). Apa yang dimaksud dengan Data Time Series. https://www.dictio.id/apa-yangdimaksud-dengan-data-time-series/106512/3

Fahmi, I. (2017). Analisis Kinerja Kenangan. Alfabeta.

Farihah, S. M., \& Setiawan, S. (2020). Determinan Intellectual Capital terhadap Profitabilitas di Bank Syariah : Pengujian Mediasi Kinerja Keuangan dan Kinerja Non Keuangan Determinant of Intellectual Capital on Profitability in Islamic Banks: Testing Mediation of Financial Performance and No. Jurnal Samudra Ekonomi Dan Bisnis, 11(28), 151-165. https://doi.org/10.33059/jseb.v11i2.1996

Fitrianti, R. D. (2015). Analisis Perbandingan Kinerja Keuangan pada Perusabaan BUMN Sektor Konstruksi Sebelum dan Sesudah Go Public (Studi Kasus PT Waskita Karya Tbk). Universitas Lampung.

Hijriyani, N. Z., \& Setiawan, S. (2017). Analisis profitabilitas perbankan syariah di indonesia sebagai dampak dari efisiensi operasional. Jurnal Kajian Akuntansi, 1(2), 194-209. http://jurnal.unswagati.ac.id/index.php/jka

Husnan, S. (2007). Dasar-dasar Manajemen Keuangan Edisi Keempat Cetakan Pertama. UPP STIM YKPN.

IAI. (2010). Pernyataan Standar Akuntansi Keuangan (PS AK) Nomor 36 tentang Akuntansi Asuransi Jiwa.

JMA Syariah. (2020). Laporan Keuangan Tabunan periode 2015-2019. https://www.jmasyariah.com/

Kasiram, M. (2008). Metodologi Penelitian Kualitatif-Kuantitatif. UIN-Maliki Press (Anggota IKAPI).

Menteri Keuangan RI. (2003). Keputusan Menteri Kenangan Republik Indonesia Nomor 424/KMK.06/2003 tentang Kesehatan Keuangan Perusabaan Asuransi dan Perusabaan Reasuransi.

Menteri Keuangan RI. (2012). Peraturan Menteri Keuangan Republik Indonesia Nomor 53/PMK.010/2012 tentang Kesehatan Keuangan Perusabaan Asuransi dan Perusabaan Reasuransi.

Nurdin, A. A., Mai, M. U., \& Setiawan, S. (2020). Pola Kinerja Perusahaan Sesudah Merger dan Akuisisi serta Analisis Terhadap Faktor-Faktor yang Mempengaruhinya. Jurnal Riset Akuntansi 
dan Keuangan, 8(2), 431-446.

Nurfadila, S., Hidayat, R. R., \& Sulasmiyati, S. (2015). Analisis Rasio Keuangan dan Risk Based Capital untuk Menilai Kinerja Keuangan Perusahaan Asuransi (Studi pada PT Asei Reasuransi Indonesia (Persero) Periode 2011-2013). Jurnal Administrasi Bisnis JAB), 22(1), 1-9. administrasibisnis.studentjournal.ub.ac.id

OJK. (2016). Peraturan Otoritas Jasa Kenangan Nomor 69/POJK.05/2016 tentang Penyelenggaraan Usaha Perusabaan Asuransi Perusabaan Asuransi Syariah, Perusabaan Reasuransi dan Perusabaan Reasuransi Syariah.

OJK. (2019). Statistik IKNB Syariah Bulan November periode 2015-2019. https://www.ojk.go.id/id/kanal/syariah/data-dan-statistik/iknb-syariah/Default.aspx

Republik Indonesia. (2014). Undang-Undang Republik Indonesia Nomor 40 tentang Perasuransian.

Rudianto. (2013). Akuntansi Manajemen Informasi untuk Pengambilan Keputusan Strategis. Penerbit Erlangga.

Setiawan, S., Wulansari, P., \& Dewi, R. P. K. (2020). Pengukuran Tingkat Kinerja Keuangan Dan Kinerja Non Keuangan Pada Bank Syariah Di Lima Negara Asia (Studi Kasus pada Bank Syariah dengan Aset Tertinggi). Dinamika Akuntansi Kenangan dan Perbankan, 9(1), 69-78.

Setyowati, H. D. (2019). Analisis Kinerja Keuangan Bank Umum Syariah Sebagai Dampak Inefisiensi Operasional. Jurnal Maps (Manajemen Perbankan Syariab), 1-14.

Setyowati, D. H., Sartika, A., \& Setiawan, S. (2019). Faktor-Faktor yang Mempengaruhi Pangsa Pasar Industri Keuangan Syariah Non-Bank. Jurnal Iqtisaduna, 5(2), 169-186.

Sugiyono. (2012). Metode Penelitian Kuantitatif dan Kualitatif dan R\&D. Alfabeta.

Taruna, R. D., \& Setiawan, S. (2019). Pengaruh Kinerja Keuangan Terhadap Pertumbuhan Laba Bank Umum di Indonesia. Jurnal Accounting Information System (AIMS), 2(1), 69-78.

Widjaja, G., \& Risnamanitis, W. (2009). Seri Pengetahuan Pasar Modal: Go Public dan Go Private di Indonesia. Kencana Predana Media Group.

Wulandari, D. (2011). Analisis Kinerja Keuangan Berdasarkan Early Warning System Pada PT Prudential Life Assurance Indonesia. Jurnal Akuntansi, 1-13. 